\title{
Microbiological Hazards Assessment of Psychrotrophic Microflora in Bovine Carcasses Slaughtered in North West Romania
}

\author{
Silviu VIDA, Alexandra TĂBĂRAN, Oana Lucia REGET, Alina Ioana FĂT, Marian MIHAIU, \\ Sorin Daniel DAN* \\ Department of Animal Production and Food Safety, University of Agricultural Sciences and Veterinary \\ Medicine, Faculty of Veterinary Medicine, 3-5 Mănăștur Street, 400372, Cluj Napoca, Romania \\ *corresponding author: sorindan@usamvcluj.ro
}

Bulletin UASVM Veterinary Medicine 73(2) / 2016,

Print ISSN 1843-5270; Electronic ISSN 1843-5378

DOI:10.15835/buasvmcn-vm: 12233

\begin{abstract}
Gram negative bacteria have the greatest capacity to spoil the meat if kept under aerobic conditions, therefor the member s of the genera Pseudomonas, Acinetobater, Psychrobacter and Moraxella, will form the dominant microflora. The purpose of this study was to assess the contamination level with psychrotropic microflora of bovine carcasses in order to prove how the results could be used to improve the slaughter process. The research was carried out between January-December 2015, in two slaughterhouses from North West Romania. The research material was represented by 144 meat samples (slaughterhouse $A, n=72$, slaughterhouse $B, n=72$ ). Weekly, 3 samples were collected from refrigerated carcasses, and examined for total psychrotrophic counts (TPC), Enterobacteriaceae, Pseudomonas, Aeromonas and Yersinia. From statistical processing of recorded data was established that mean log TPC from the surface of refrigerated carcasses has presented different values, ranged between $3.70 \pm 0.20 \log$ CFU/ $\mathrm{cm}^{2}$ and $6.90 \pm 0.43 \log \mathrm{CFU} / \mathrm{cm}^{2}$. Initial surface microflora of bovine carcasses was represented by germs from the following genera: Staphylococcus, Micrococcus, Aeromonas, Acinetobacter, Pseudomonas, Yersinia, Serratia, Hafnia, Proteus and Escherichia. Microbiological hazard assessment reveals the key role of psychotropic microorganisms in the spoilage of meat, if the monitoring system of the slaughtering process is not functioning properly.
\end{abstract}

Keywords: microbiological hazards, psychrotrophic bacteria, bovine carcasses, hygiene, slaughterhouse.

\section{INTRODUCTION}

Taking into account the fact that one of the most requested food in the majority of the countries is meat, it is necessary for this product to be processed in the best sanitary conditions. Meat, because of its chemical composition, is highly susceptible to microbial alteration, being involved also in spreading of some diseases or in the onset of food poisoning episodes. Because of that, the researchers' interest regarding meat and meat products' role in the onset of these food poisoning episodes has begun to increase, instead of decreasing.

The microorganism's presence in meat (microbiological hazard), plays a major role in the quality, sanitary and freshness state, because the quality of meat can increase or decrease, becoming improper for consumption according to the influence of these particular factors. This outcome is due to their pathogenic actions, or because of the toxic metabolic products resulting after the microorganism's degradation. Bovine carcasses can become contaminated during the technological process with a variety of altering microorganisms or conditionally pathogenic bacteria, which can be found in various sources (e.g. soil, water, equipment, knives, faeces, operators), but only some of these are able to grow in the environments' conditions, and only a few will be able, eventually, to start spoilage processes (Gill, 1997; 1998). The 
Gram negative bacteria have the greatest meat and meat products' spoiling capacity. In case they are kept in aerobic conditions, the members of Pseudomonas, Acinetobater, Psychrobacter and Moraxella species, due to their high growing rate, will become the dominant microflora (Molin and Ternstrom, 1982; Molin et al., 1986; Shaw and Latty, 1982, 1984, 1988; Prieto et al., 1992 a, b; Drosinos and Board 1995; Davies and Board, 1998). Certain species of psychrotrophic Enterobacteriaceae commonly occur on chilled meat, but appear to be more prevalent on pork and lamb (Grau, 1981; Dainty and Mackey,1992). The enumeration of Enterobacteriaceae on selective media has shown that certain genera of this family are significant, but not dominant, members of the microbial associations on meats stored aerobically at chill temperatures (Dainty et al., 1989). Serratia liquefaciens, together with Enterobacter aerogenes and Citrobacter spp., were found on lamb chops (Newton et al., 1977). Isolation of Flavobacterium, Alcaligenes, Vibrio, Aeromonas and Alteromonas is reported less frequently (Patterson and Gibbs, 1977; Nottingham, 1982).

Based on these facts and taking into account that in the beef slaughtering units from the North West region of Romania a research of this kind hasn't been made, we tried to assess the microbiological hazards represented by the psychrotrophic germs, in two slaughtering units.

\section{MATERIALS AND METHODS}

\section{Materials}

The research material was represented by 144 beef samples, collected during January December 2015, from two beef slaughtering units located in the north west region of Romania (slaughterhouse $A, n=72$, slaughterhouse $B, n=72$ ). Weekly, 3 samples were collected at four sites from refrigerated carcasses, and examined for total psychrotrophic counts (TPC), Enterobacteriaceae, Pseudomonas, Aeromonas and Yersinia. The day of sampling was changed each week. The samples were obtained by the destructive sampling technique from four different sites stipulated by the Commission Decision 2001/471/CE (e.g. neck, brisket, flank, and rump). Four flaps of superficial muscle tissue from the carcasses surface were collected, each having a thickness of 2-3 $\mathrm{mm}$, and $20 \mathrm{~cm}^{2}$. Samples were subsequently placed into cool boxes, and microbiological examinations were carried out 2-4 h after sampling, in the Animal Food Hygiene and Public Health laboratory from the Faculty of Veterinary Medicine, Cluj-Napoca.

\section{Sample preparation}

Samples of each carcass were homogenized together for $120 \mathrm{sec}$. in $100 \mathrm{ml} 0.1 \%$ buffered peptone water and $0.85 \%$ sodium chloride solution in a stomacher Easymix (AES Chemunex, Bruz, FR). Serial dilutions were aseptically prepared and plated on various selective and differential media.

\section{Microbiological analysis}

Suspensions were plated with a spiral plater (Autoplate 4000, Spiral Biotech, Bethesda, MD) on plate count agar (Merck, KGaA, Darmdstadt, Germany), violet red bile glucose agar (VRBD agar, Merck, KGaA, Darmdstadt, Germany), Pseudomonas Aeromonas selective agar (GSP agar, Merck, KGaA, Darmdstadt, Germany), Yersinia selective agar (CIN agar Merck, KGaA, Darmdstadt, Germany). For samples in which bacterial counts were below the detection limit, a log value of zero was used for calculations. Microbiological results were depicted as time trend graphs of trimestrial mean log values. All plates were incubated aerobically for $48-72 \mathrm{~h}$ at $20^{\circ} \mathrm{C}$ (Nottingham, 1982; Greer, 1981, 1982). Manual counting was applied. In order to identify the pshychrotrophic germs, from the grown colonies in the dehydrated selective media there were microscopic exams made (Gram staining), followed by biochemical confirmation tests: API 20E and API 20NE (bioMérieux SA Marcy l'Etoile, France).

\section{Statistical analysis}

All statistical analysis were performed using the Origine 8.5 software (OriginLab Corporation, Northampton, USA). For all tests, a significance level of $p=0.05$ was chosen. To evaluate significant differences in TPC between abattoirs, one-way analysis of variance (ANOVA) was performed. Bonferroni post-hoc procedure was used for paired comparisons when ANOVA yielded significant results.

\section{RESULTS AND DISCUSSION}

The average psychrotrophic load at the refrigerated carcasses in the samples collected from unit $\mathrm{A}$ has shown different values, ranging between $3.70 \pm 0.20 \log \mathrm{CFU} / \mathrm{cm}^{2}$ in the first trimester and $6.90 \pm 0.43 \mathrm{log} \mathrm{CFU} / \mathrm{cm}^{2}$ in the third trimester, with a minimum value of $3.2 \pm 0.1 \mathrm{log}$ $\mathrm{CFU} / \mathrm{cm}^{2}$ in January and a maximum of $7.33 \pm 0.20$ 
$\log \mathrm{CFU} / \mathrm{cm}^{2}$ in September (Fig. 1). The highest values of the microbial load was noticed during the second and third trimester, when it was revealed an exceeding in the recommended maximum limit (5.0 log $\mathrm{CFU} / \mathrm{cm}^{2}$ ) at 32 samples (44.44\%) (Sutherland et al., 1975; Hanna et al., 1977; Ayres et al., 1980; Cousin, 2000). The psychrotrofic germ load in the case of the samples collected in unit B, ranged between $5.46 \pm 0.14 \log \mathrm{CFU} / \mathrm{cm}^{2}$ in the first trimester and $6.04 \pm 0.51 \mathrm{log} \mathrm{CFU} / \mathrm{cm}^{2}$ in the third trimester with minimum values of $5.30 \pm 0.20 \mathrm{log}$ $\mathrm{CFU} / \mathrm{cm}^{2}$ in the month of January and a maximum of $7.16 \pm 0.05 \log \mathrm{CFU} / \mathrm{cm}^{2}$ in May, noticing that at 17 samples the value was higher than the limit recommended, which means $72 \%$, from the total samples' number (Fig. 1).

Similar values were obtained by Brown (2000), which revealed in the refrigerated bovine carcasses values ranging between $5.54 \log \mathrm{CFU} / \mathrm{cm}^{2}$ and 8.0 $\log \mathrm{CFU} / \mathrm{cm}^{2}$. Also, Roberts $(1980,1997)$, in his studies concerning the psychrotrophic load at the refrigerated bovine carcasses, has obtained values between $4.50 \log \mathrm{CFU} / \mathrm{cm}^{2}$ and $7.0 \log \mathrm{CFU} / \mathrm{cm}^{2}$.

The logarithmic average of the pseudomonads load in unit A was in between 4.98 $\pm 0.45 \log \mathrm{CFU} /$ $\mathrm{cm}^{2}$ in the third trimester and $6.07 \pm 0.33 \mathrm{log}$ CFU/ $\mathrm{cm}^{2}$ in the second trimester, with a minimum value of $4.53 \pm .040 \log \mathrm{CFU} / \mathrm{cm}^{2}$ in August and a maximum value of $6.4 \pm 0.26 \mathrm{log} \mathrm{CFU} / \mathrm{cm}^{2}$ in May. In regard to unit $\mathrm{B}$, the obtained results show that the average germ load belonging to this genus is higher, ranging between $4.62 \pm 0.34 \log \mathrm{CFU} / \mathrm{cm}^{2}$ in the first trimester and $6.27 \pm 0.18 \mathrm{log} \mathrm{CFU} / \mathrm{cm}^{2}$ in the third trimester, with a minimum of $4.33 \pm 0.41$ $\log \mathrm{CFU} / \mathrm{cm}^{2}$ in February and a maximum of $7.13 \pm 0.15 \log \mathrm{CFU} / \mathrm{cm}^{2}$ in August (Fig. 2).

From the total of 72 samples collected from the bovine carcasses' surface, in the units studied, at 54 samples $(75 \%)$ the development of specific Aeromonas spp. colonies was noticed.

After evaluating the results, in unit A we found that the average germ load from Yersinia genus was in between $4.20 \pm 0.26 \log \mathrm{CFU} / \mathrm{cm}^{2}$, during the first trimester and $5.78 \pm 0.44 \log \mathrm{CFU} / \mathrm{cm}^{2}$ in the third trimester. Regarding the samples collected from unit B, the Yersinia average germ load was in between the value of $4.5 \pm 0.4 \log \mathrm{CFU} / \mathrm{cm}^{2}$ during the fourth trimester and $6.13 \pm 0.63$ during the third trimester, with a minimum value of $4.066 \pm 0.30 \mathrm{log}$ $\mathrm{CFU} / \mathrm{cm}^{2}$ in May and a maximum of $6.8 \pm 0.30 \mathrm{log}$ $\mathrm{CFU} / \mathrm{cm}^{2}$ in the course of September.

The average load of germs belonging to Enterobacteriaceae family in unit A was found to range between the values of $2.0 \pm 0.03 \log \mathrm{CFU} /$ $\mathrm{cm}^{2}$ during the fourth trimester and $5.65 \pm 0.21$ $\log \mathrm{CFU} / \mathrm{cm}^{2}$ during the fourth trimester, with a minimum value in January of $1.96 \pm 0.40 \log$ CFU/ $\mathrm{cm}^{2}$ and a maximum one of $5.86 \pm 0.11 \log \mathrm{CFU} / \mathrm{cm}^{2}$ in August. The results revealed that from the total number of samples, 50 of them have higher values than the maximum one allowed $\left(2.5 \log \mathrm{CFU} / \mathrm{cm}^{2}\right)$ (69.44\%), the lowest ones being registered in the fourth trimester. Regarding the results found in the samples collected at unit B, we revealed that the average number of Enterobacteriaceae was higher than of that found in unit $\mathrm{A}$, ranging between

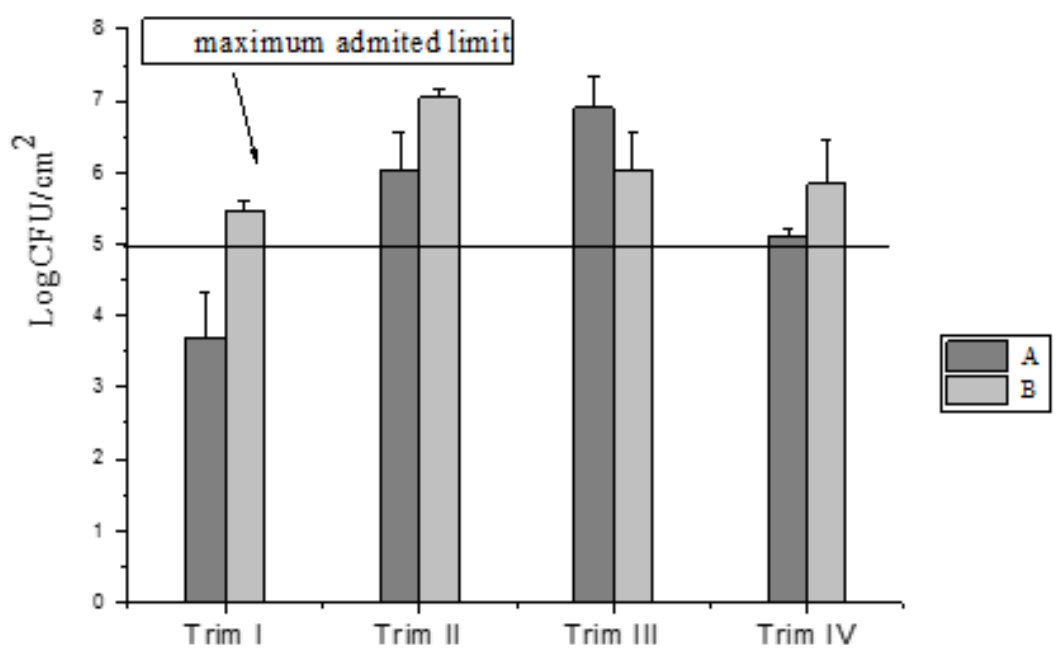

Fig. 1. Mean log values of total psychrotrophic count at the surface of refrigerated beef carcasses from $A(n=72)$ and $B(n=72)$ slaughterhouses 
$3.77 \pm 0.17 \log \mathrm{CFU} / \mathrm{cm}^{2}$ during the fourth trimester and $6.07 \pm 0.24 \log \mathrm{CFU} / \mathrm{cm}^{2}$ during the third one, in all the samples the maximum allowed value being crossed over (Fig. 3).These higher values of the Enterobacteriaceae load revealed the lack of proper conditions in the carcasses processing on the entire flow diagram and the inconsistency with the good manufacturing practices (GMP), respectively with the good hygiene practices (GHP) especially at the evisceration of the organs from the abdominal and pelvic cavity. On the basis of our observations made on the units taken into study we found that both of the slaughtering units have not performed the double ligatures of the esophagus, pylorus, and that the plastic bag were not applied at the anus, in order to prevent the germ contamination of the carcasses from the lower digestive tract.

Another major source of carcasses' surface contamination was represented by the beef's tegument, in terms in which the skinning was made manually. In this way, a contamination of the subcutaneous conjunctive tissue has been made with the germs present on the knives and hands, especially if the hygiene operation of the hands and equipment was not done properly. Following these aspects, the results obtained are explainable in what concerns the microbial contamination

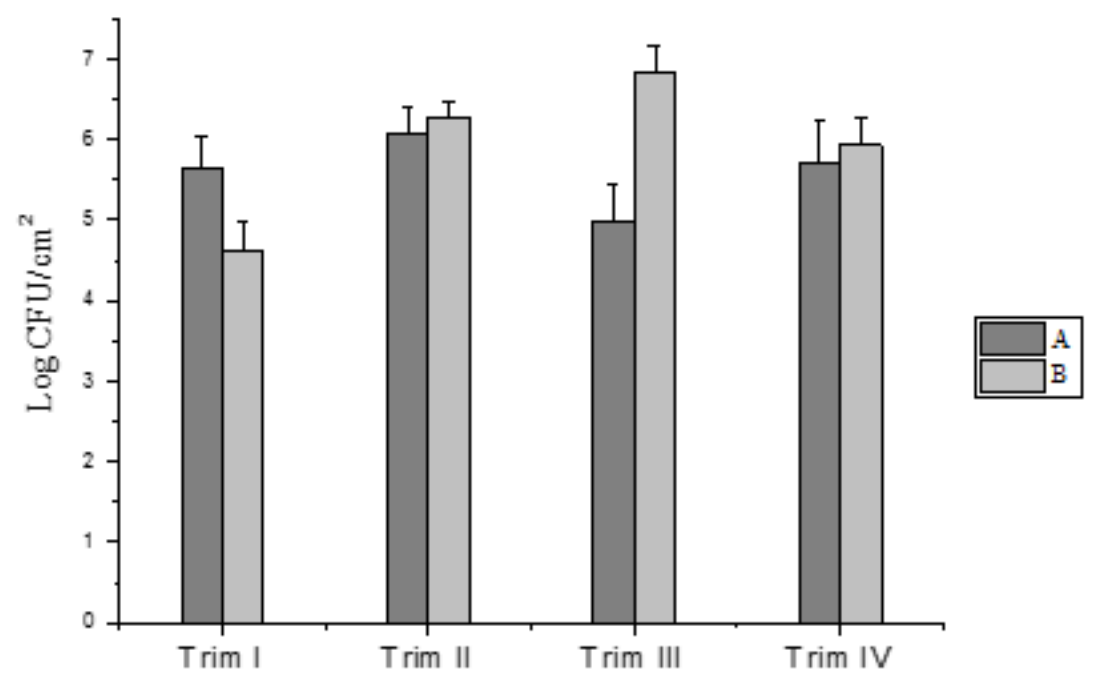

Fig. 2. Mean log value of Pseudomonas plate count at the surface of refrigerated beef carcasses from $A(n=72)$ and $B(n=72)$ slaughterhouses

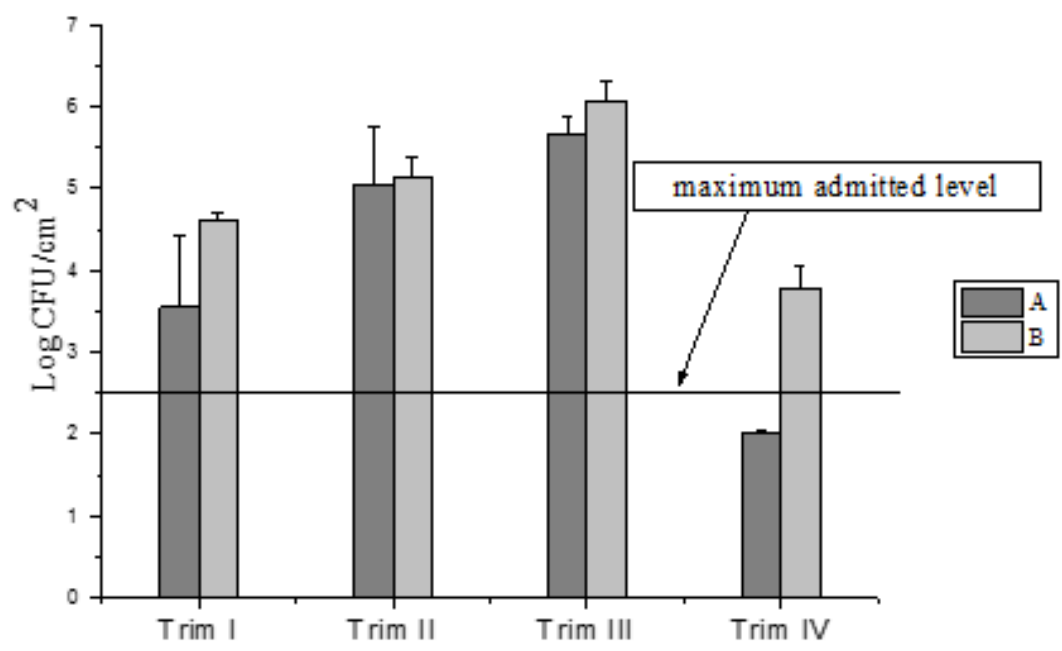

Fig. 3. Mean log value of Enterobacteriaceae plate count at the surface of refrigerated beef carcases from $A(n=72)$ and $B(n=72)$ slaughterhouses 
with Enterobacteriaceae germs at the surface of the refrigerated carcasses.

Comparing the results obtained in the evaluation of the total germ load from the warm carcasses surface samples with the ones taken from the refrigerated ones in unit A we revealed statistically significant differences regarding the psychrotrophic microflora (Tab. 1).

Based on these results we can conclude that by keeping the carcasses at refrigerating temperatures, the spoiling psychrotrophic germs or conditionally pathogenic, have the capacity of multiplying very fast compared to the mesophilic spoiling germs, becoming one of the dominant microorganism in the meats' ecosystem (Jackson et al., 1997, Gill, 1986; Day, 2000). Following this aspect, the psychotrophic germs will start alterative processes in meat as soon as their number reaches rapidly values of $10^{6}-10^{7} \mathrm{CFU} /$ $\mathrm{cm}^{2}$ (Ayres, 1980; Gill, 1986).
After the statistical evaluation of the results shown in figure 4, we have noticed that the Gram negative bacteria represent $78.64 \%$, while the Gram positive ones have a lower occurrence of $21.36 \%$, being represented by staphylococci, micrococci and unidentified Gram positive bacilli. The Gram positive bacteria were identified only on the account of the morphological exam (microscopic), catalase and oxidase tests. From the Gram negative bacteria group, the psychrotrophic germs are predominant, represented by Pseudomonas genus (25.79\%), Aeromonas genus (11.95\%), Psychrobacter genus (10.14\%), Acinetobacter genus (7.24\%), and Yersinia genus (6.51\%). The psychrotrophic members from the Enterobacteriaceae family were identified using the API $20 \mathrm{E}$ kits and were represented only by the alteration germs, like the following ones: Hafnia alvei (3.98 \%), Serratia lignefaciens (5.79\%) and Pantoea spp. $2(1.09 \%)$ (Fig. 4).

Table 1. Significance level of differences between psychrotrophic plate count from the surface of warm bovine carcasses compared with the surface of chilled bovine carcasses in A and B slaughterhouse

\begin{tabular}{|c|c|c|c|c|c|c|}
\hline \multirow{3}{*}{ PARAMETERS } & \multicolumn{3}{|c|}{ A slaughterhouse } & \multicolumn{3}{|c|}{ B slaughterhouse } \\
\hline & \multicolumn{2}{|c|}{ ANOVA } & \multirow{2}{*}{$\begin{array}{c}\text { BONFERRONI } \\
\text { Significance } \\
\text { level }\end{array}$} & \multicolumn{2}{|c|}{ ANOVA } & \multirow{2}{*}{$\begin{array}{c}\text { BONFERRONI } \\
\text { Significance } \\
\text { level }\end{array}$} \\
\hline & $P$ value & $\begin{array}{c}\text { Significance } \\
\text { level }\end{array}$ & & $\begin{array}{c}P \\
\text { value }\end{array}$ & $\begin{array}{c}\text { Significance } \\
\text { level }\end{array}$ & \\
\hline Total psychrotrophic count & 0.007 & $\mathrm{p} \leq 0,01$ & $\mathrm{p} \leq 0,01$ & 0.02 & $\mathrm{p} \leq 0,05$ & $\mathrm{p} \leq 0,05$ \\
\hline Pseudomonas spp. count & 0.000 & $\mathrm{p} \leq 0,001$ & $\mathrm{p} \leq 0,001$ & 0.0001 & $\mathrm{p} \leq 0,001$ & $\mathrm{p} \leq 0,001$ \\
\hline Aeromonas spp. count & 0.02 & $\mathrm{p} \leq 0,05$ & $\mathrm{p} \leq 0,05$ & 0.0003 & $\mathrm{p} \leq 0,001$ & $\mathrm{p} \leq 0,001$ \\
\hline Yersinia spp. count & 0.03 & $\mathrm{p} \leq 0,05$ & $\mathrm{p} \leq 0,05$ & 0.01 & $\mathrm{p} \leq 0,05$ & $\mathrm{p} \leq 0,05$ \\
\hline Enterobacteriaceae count & 0.002 & $\mathrm{p} \leq 0,01$ & $\mathrm{p} \leq 0,01$ & 0.0003 & $\mathrm{p} \leq 0,001$ & $\mathrm{p} \leq 0,001$ \\
\hline
\end{tabular}
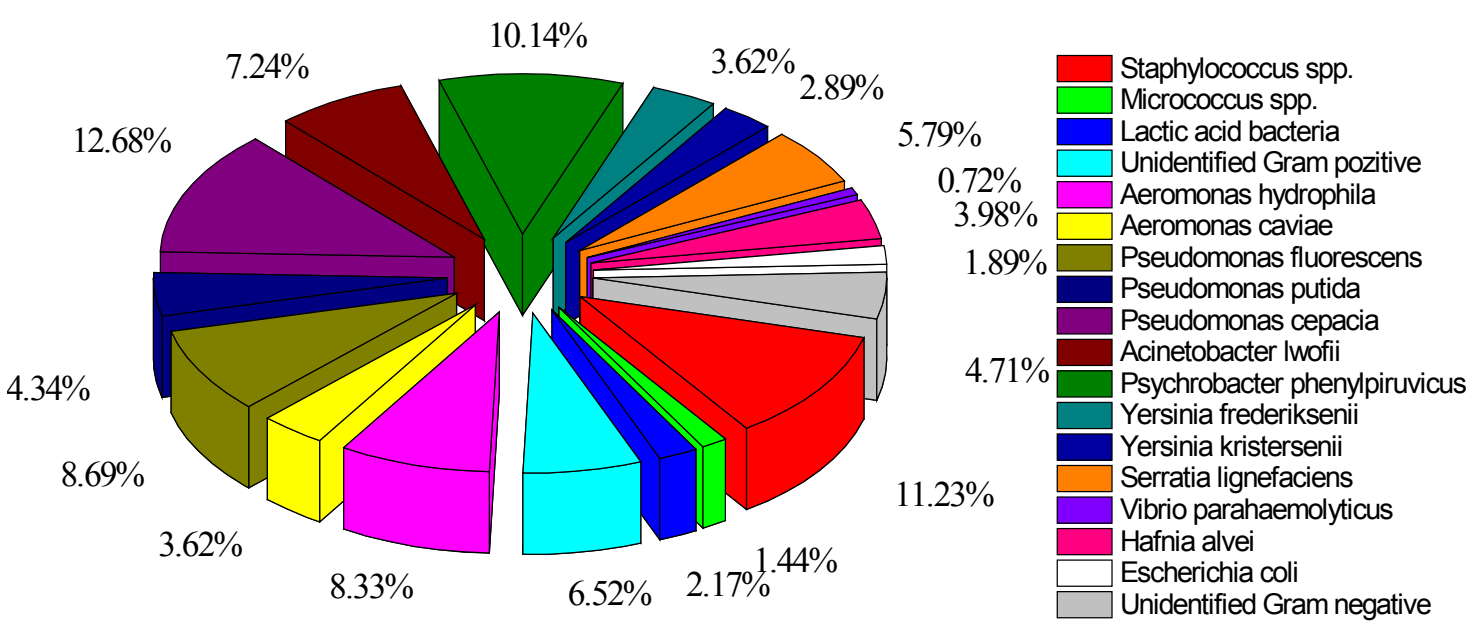

Fig. 4. The incidence of bacterial species at the surface of refrigerated beef carcasses from B slaughterhouse 
Comparing the results concerning the configuration and prevalence of the identified species from the warm bovine carcasses' surface with the ones obtained at the refrigerated samples we revealed that if the initial flora was predominant by the Gram positive (56.51\%), the psychrotrophic germs having a lower value (37.17\%), after the chilling conditions ( $48 \mathrm{~h}$ ), a major change took place in the microbial configuration, because of the new environmental conditions. In this respect, the dominant microflora is in fact the Gram negative one (73.98\%), among which the psychrotrophic bacteria is represented in large numbers (71.39\%), following these microorganisms' properties of rapidly growing at refrigerating temperatures, compared to the mesophilic microflora. Similar studies made by Sutherland et al. (1975), Hanna et al. (1977), Ayres et al. (1980) and Cousin (2000), have revealed that the initial microflora in the bovine carcasses is dominated by the Gram positive represented by staphylococci, micrococci, streptococci, Bacillus and Lactobacillus germs, in variable amounts, ranging between $55-75 \%$, while the Gram negative microflora is represented by the genera: Pseudomonas, Acinetobacter, Moraxella, Aeromonas, accounting for approximately $25-45 \%$. At refrigerating tempretures, there is a change in the microbial configuration which takes place, so that, the psychrotrophical germs, represented by the microorganisms from the genera Pseudomonas (54\%), Moraxella (9\%), Acinetobacter (10\%), Aeromonas (9\%), Psychrobacter along with a lower quantity of psihrotrophic germs from the Enterobacteriaceae family (Serratia, Enterobacter), become the dominant population (Cousin, 2000).

\section{CONCLUSIONS}

The microbiological hazards assessment performed at bovine carcasses proves the key role of the psychrotrophic bacteria in the meat's spoilage processes, when a deficient monitoring of slaughter technology occurs. In order to decrease these high incidences of micro-organisms it is recommended that significant improvements be implemented with regard to compliance with good hygiene practices and good manufacturing practices, within the abattoir and especially in the skinning and evisceration area, where the carcasses are exposed to considerable contamination. From these results it is obvious that the existing food safety assurance system within the abattoir often fails to produce meat that complies with the Regulation 1441 (CE)/2007. The data obtained during this study will furthermore be used to improve the existing quality assurance program at the specific abattoir and should thus contribute to the delivery of a safe product to the consumer.

\section{REFERENCES}

1. Ayres JC, Mundt JO, Sandine WE (1980). Microbiology of Foods, W.H. Freeman and Company, San Francisco,USA.

2. Brown HM (2000). Processed meat products. In The Microbiological safety and Quality of Food, Vol. I, Lund BM, Baird-Parker TC, Gould GW, (eds.) Aspen Publishers, Inc., Gaithersburg, Maryland pp. 389-419.

3. Commission Decision No 2001/471/CE of 8 June 2001 laying down rules for the regular checks on the general hygiene carried out by the operators in establishments according to Directive 64/433/EEC on health conditions for the production and marketing of fresh meat and Directive 71/118/EEC on health problems affecting the production and placing on the market of fresh poultry meat.

4. Commission Regulation No 1441/2007 of 5 December 2007 amending Regulation No 2073/2005 on microbiological criteria for foodstuffs.

5. Cousin MA, (2000). Pseudomonas. In Encyclopedia of Food Microbiology, Vol. III, Robinson RK, Batt CA, Patel PD (eds.), Academic Press, San Diego, California pp. 18641867.

6. Dainty RH, Edwards RA, Hibbard CM, Marnewick JJ (1989). Volatile compounds associated with microbial growth on normal and high $\mathrm{pH}$ beef stored at chill temperatures. J. Appl. Bacteriol.. 61: 117-23.

7. Dainty RH, Mackey BM (1992). The relationship between the phenotypic properties of bacteria from chill-stored meat and spoilage processes. J. Appl. Bacteriol., 73 Symp. Suppl. 21: 103s-114s.

8. Davies AR Board RJ (1998). The Microbiology of Meat and Poultry, Blackie Academic \& Professional, London, UK.

9. Day BPF (2000). Chilled storage of food. In Encyclopedia of Food Microbiology, Vol. I, Robinson RK, Batt CA, Patel PD (eds.), Academic Press, San Diego, California pp. 403410.

10. Drosinos EH, Board RG (1995). Microbial and physicochemical attributes of minced lamb: sources of contamination with pseudomonads. Food Microbiol 12: 189-197.

11. Gill CO (1986). The control of microbial spoilage in fresh meats. In Pearson AM, Dutson TR (eds.). Advances in meat research: meat poultry microbiology, Macmillan, London, UK, pp. 49-88.

12. Gill CO, Bryant J (1997). Assessment of the hygienic performance of two beef carcass cooling processes from product temperature history data or enumeration of bacteria on carcass surfaces. Food Microbiology 14: 593602 . 
13. Gill CO, Deslandes B, Rahn K, Houde A, Bryant J (1998). Evaluation of the hygienic performances of the processes for beef carcass dressing at 10 packing plants. Journal of Applied Microbiology 84: 1050-1058.

14. Grau FH (1981). Role of $\mathrm{pH}$, lactate, and anaerobiosis in controlling the growth of some fermentative Gramnegative bacteria on beef. Appl Environ Microbiol 42: 1043-50.

15. Greer GG (1981). Rapid detection of psychrotrophic bacteria in relation to retail beef quality. J Food Sci 46: 1669-1672.

16. Greer GG (1982). Psychrotrophic bacteriophages for beef spoilage pseudomonads, J Food Protect 45: 1318-1325.

17. Hanna MO, Stewart JC, Carpenter ZI, Vanderzant C (1977) Development of Yersinia enterocolitica on raw and cooked beef or pork at different temperatures. J Food Sci 42(5): 1180-1185.

18. Jackson TC, Acuff GR, Dickson JS (1997). Meat, poultry, and seafood. In Doyle MP, Beuchat LR, Montville TJ (eds.) Food Microbiology: 4 Fundamentals and Frontiers, ASM Press, Washington DC, pp. 83-100.

19. Molin G, Ternstrom A (1982). Numerical taxonomy of psychrotrophic pseudomonads. J Gen Microbiol 128: 1249-1264.

20. Molin G, Ternstrom A, Ursing J (1986). Pseudomonas lundensis, a new bacterial species isolated from meat, Int J System 36: 339-42.

21. Nesbakken $T$ (2000). Yersinia species. In The Microbiological safety and Quality of Food, Vol. II, Lund BM, Baird-Parker TC, Gould GW, (eds.) Aspen Publishers, Inc., Gaithersburg, Maryland pp. 1363-1393.

22. Newton KG, Harrison JCL, Smith KM (1977). Coliforms from hides and meat. Appl Environ Microbiol 333: 199200.
23. Nottingham PM (1982). Microbiology of carcass meat. In Meat Microbiology, Brown MH (ed.), Applied Science, London, UK pp. 13-65.

24. Patterson, JT, Gibbs PA (1977). Incidence and spoilage potential of isolates from vacuum-packaged meat of high pH value, J Appl Bacteriol 43: 25-38.

25. Prieto M, Garcia-Armesto MR, Garcia-Lopez ML (1992). Numerical taxonomy of Gram-negative, nonmotile, nonfermentative bacteria isolated during chilled storage of lamb carcasses. Appl Environ Microbiol 58: 2245-9.

26. Prieto M, Garcia-Armesto MR, Garcia-Lopez ML (1992). Species of Pseudomonas obtained at $7^{\circ} \mathrm{C}$ and $30^{\circ} \mathrm{C}$ during aerobic storage of lamb carcasses. J Appl Bacteriol 73: 317-323.

27. Roberts TA (1980). The effects of slaughter practices on the bacteriology of the red meat carcass, Royal Society of Health Journal 80: 3-9.

28. Roberts TA (1997). Microbial growth and survival: developments in predictive modeling, Food Technology, 51 (4): 88-90.

29. Shaw BG, Latty JB (1982). Numerical taxonomic study of Pseudomonas strains from spoiled meat. J Appl Bacteriol 52: 219-28.

30. Shaw BG, Latty JB (1984). A study of the relative incidence of different Pseudomonas groups on meat using a computer-assisted identification technique employing only carbon source tests. J Appl Bacteriol 57: 59-67.

31. Shaw BG, Latty JB (1988). A numerical taxonomic study of non-motile non-fermentative Gram-negative bacteria from foods. J Appl Bacteriol 65: 7-21.

32. Sutherland JP, Patterson JT, Murray JG (1975). Changes in the microbiology of vacuum-packed beef. J Appl Bacteriol 39: 227-232. 